Global Conferences Series:

Social Sciences, Education and Humanities (GCSSSEH), Volume 2, 2019

The $2^{\text {nd }}$ International Conference on Sustainable Development \& Multi-Ethnic Society

DOI: https://doi.org/10.32698/GCS.0183

\title{
Parent Involvement in Children Learning to Academic Excellence
}

\author{
Rosinah Hamidun ${ }^{1}$, Mohd Mahzan Awang ${ }^{2}$, Abdul Razaq Ahmad ${ }^{3}$ \& Anuar Ahmad $^{4}$ \\ ${ }^{1234}$ Faculty of Education UKM, MALAYSIA \\ E-mail: inaosinah07@yahoo.com
}

\begin{abstract}
This writing discusses concepts of a child's learning towards academic excellence with the aid of parents. Parents act as partners in improving schools and ensuring quality learning outcomes of their children. During a child's progress and process in gaining knowledge alongside with parents' involvement, the development of the child as an individual is greatly influenced. This study aims to investigate how parents can do their part in involving with their children's education and to have views on the effects it imposes upon the academic achievement of students. The results showcase that the model of parental involvement initiated by Joyce Epstein is a model that discusses on parents' involvement in boosting their children's learning activities. This model can be used as a guide in planning various activities to encourage parents to be actively getting themselves engaged in children's learning activities. A variety of activities should be built to attract attention and encourage engagement of parents alongside with schools in children's learning activities in accordance with the requirements of the government which shows the importance of educating children in early age. Overall, the study found that the willingness of parents in getting involved with their children's education will drive the children to create successes in life.
\end{abstract}

Keywords: Parental Involvement, Academic Achievement, Learning Children

\section{Introduction}

Based on research done by Garcia and Thornton (2014:1) it is shown how effective when family interferes in the child's progress in education. This indirectly aids in improving students' performance, slash down the rate of absence to school as well as embedding parents' confidence in their children's education. It is also noticed that students have been progressing so well in their education through higher grades and scores, enhance their ability to socialise also having better manners around their parents and caregivers. This is something remarkable as we as a community and wholly as a part of the gigantic global population are in need of contribute in reducing crime and poverty. Thus, at ideal, the stress on making sure parents get themselves involved is for real as it is vital in this scenario. Later on, how parents effectively get themselves involved is deeply revised in depth in this case study and is observed by focusing on: the ideology of parental engagement, its issue and problems, the challenges faced by parents and also some sort of useful suggestions.

\section{Concept of Parental Involvement}


In a situation when parents get themselves involved, a few perspectives can be seen and discussed from few perspectives: 1) involvement of parents directly in a child's education in the aspect of learning processes in schools is further enhanced in which teachers also feel at ease .2) learners are to be having guidance in learning as much as the possibly can when parents are aware of being responsible thus fulfilling their duties. In this context, it is not simply just an act on how parents enquire on how well their children perform in schools, but playing their part in making sure of having a healthy bond with their children. Thus, (Clinton \& Hattie, 2013:324) also justified that in having progresses, it is important to motivate, coach and give out inspirations as it is genuine.

\section{Issues and Problems}

Mc Neal (2001:171) pointed out that parents that insist learners to always focus in school indirectly deteriorates the relationship between parents and learners. Some cases involve parents who always have the tendency to check on their children's attendance by calling their teachers. This creates a feeling of untrusted among learners by their parents (Llamas \& Tuazon, 2016:60)

Unfortunately, at times there are questions to why efforts in boosting parental involvement tend to go downhill. In one statement from Jones (2001, p. 42), it is stated that teachers have a lot to catch up on when it comes to managing a big group of children in equivalence of 150 families at the same time handling their hectic tentative, with some things might get missed out upon when they can't seem to find their messages. In another extract, McPherson (1972) came to an understanding that many teachers have a concern that in some circumstances, some children when being clustered in classes will be affected in terms of their well-being when parents tend to be more involved personally.

On the other hand, Becher (1986) focuses on a few reasons to why teachers are reluctant in encouraging parental involvement and this includes their stand on stressing that parental involvement slashes their capability as parents being well-known. At times, educators seem to feel that when it comes to parents engaging with their children's education, a lot of time has been taken up in terms of planning and carrying out activities and by turning the table over to parents for them to take over the responsibility of teaching is not going to work well as parents themselves tend to be uncertain of teaching and guiding their children. (Becher, 1986). Baker (1997) stated that teachers had a feeling of slight negativity when it comes to parents and had some pinch of not wanting any interaction with parents.
It is quite a shock to discover that some teachers are on all eyes to simply just stay away from parents of confronting types. Baker also emphasised that teachers would want to avoid taking blame alongside when parents getting back to them because of this issue. (Baker, as cited in Jones, 2001, p. 39). In times it gets disappointing when parents turn away in supporting teachers in managing time to start off on parental involvement (Brown, 1989). Parents may not attend meetings or sessions organised by committee in schools; sometimes parents choose to ignore in keeping up with school tasks from their children's teachers. Wagenaar (1977) reported that at times, parents found that the school itself is creating this tension as parents feel that the school is curbing them from directly involving themselves in sharing their thoughts, disappointment regarding the school and also demanding for their children. Brown (1989) expresses questions to why parents have trouble finding time in involving with school activities: parents have issues of finding quality time which is vital in engaging with school parental involvement initiatives; it is absurdly not a good way to have a reason that parents having their own career finds it difficult to steal some time during the day to attend their children's school; meanwhile in the evening, they find it not right if they were to abandon their family time over school activities; it takes a sum of money and some cost and also inconvenient to hire a babysitter; some parents have some feels of lacking in skills to lend a helping hand; past personal experiences lead some parents with past personal experiences which turns out to be a negative one are doubted to visit the school; and finally, some parents too have courtesy of not going against the main responsibility of teachers and most importantly the school administration.

Ramirez (2001) on the same page has come to an opinion that there is assumption that parents are just being busybody when they get actively involved with their children's education. However, on another note, parents are labelled as irresponsible if they choose to leave out of their business as they seem to not take into account on what is going on with their children's school. Most parents feel it is a strong to participate when they think that their contributions matter a lot and would affect how well their children perform. (McKinney, 1980) mentioned that in classroom involvements, meetings and some special sessions organised by teachers, parents feel that they have all it takes to gear up for those sorts of duties. Besides, there could be various types of parents. Some will be more than happy to be given the opportunity in deciding good steps for the school while some don't show much of an interest in meetings on various aspects especially in development in being better in career also in engaging with people through social services. Moreover, parents don't seem to also show interest in activities related to socialising and raising funds for good 
cause. However, Jones (2001) and C. Okpala, A. Okpala, and Smith (2001) stated that there are almost none of students' achievements from these sorts of activities. Okpala et al. (2001) suggested who realise that by willingy taking part in their children's academic progress in school, it will indirectly boost their progress and excellence in academic.

As a result, students take their tasks for serious and will be doing it with willingness alongside motivation and determination of their teachers.In this study, there are some writers (Dornbush et al., 1987; Lamborn et al., 1993; Steinberg et al., 1992) who had wrote about how a growing child's achievement is affected wholly when their parents get involved, Keith et al. (1986) and Natriello \& McDill (1986) found that despite immense evidence of parental involvement leading to higher student achievement in elementary schools, it's a very little result on adolescent achievements. T.Z. Keith (1991) stressed that many sorts of variations in regarding to this context of parental involvement comes from different types of definitions from various sources.

Carvalho (2001) raised upon an argument against her thoughts on parental involvement and she also mentioned in a firm manner that parents getting involved in further extends did not think about families' socioeconomic standing, culture, and feelings. Also, within the context of parental involvement initiatives, she felt that it's more towards the folks of middle-class families. Thus, she recommended that several folks don't seem to be totally capable to coach their children. The term of interactive prep is additionally not sensible enough amongst parents who are going through single-parenting, both parents of career-type, struggle in economics household and psychological problems in families. This queries why parents in their respective families are suggested to transform activities involving families sophisticated ones based on the different ways the family culture is and the free time that they have (De Carvalho, 2001).

As a fact, parents too have their own schedule and free time thus schools should not pressure parents by forcing them to participate in school activities. It's additionally understood that parents are perpetually kept updated on whether or not they are keeping themselves mindful of the academic progress of their children as well as how these children socialise amongst their peers with the need to be emotionally stable. Truth to be told, parental involvement programs showcases instructional improvement on families rather than schools. it's additionally feared the way parents act in engaging in their children's academic progress has the potential to affect the well-being of students in terms of academics between those whose parents who have everything desired in life and capable in aiding their children compared to those who don't (De Carvalho, 2001).

\section{Challenges and Suggestions}

It is also stated from Singh, Mbokodi and Msila (2004:303) that parental engagement in their children's education can at time be challenging especially if it involves parents of jobs with low income as their monthly household expenses require them to go extra miles in doing additional jobs that indirectly takes up their time mainly in guiding their children with school tasks (Chavkin \& William, 1989:21). This makes it harder for the teachers as a result of high expectancy in providing good and satisfying results alongside the fact that they're not receiving any support from the children's folks (Singh, Mbokodi \& Msila, 2004:304).

An excuse for folks to not take note is that they are aware at times that schools generally failed in making sturdy links between homes, schools and surroundings in cases where parents feel that schools are not willingly welcoming them especially among low-income parents that these feeling pops up. (Lemmer, 2007:220) also stated how it can get worse when some parents who face illiteracy in which reading and writing becomes a trouble for them thus, they genuinely depend on verbal communication and this is troublesome to guide their children in school tasks.

There are a variety of methods that school can instil to induce the ability of parents to take note of their children's academic progress and growth. This might be carried out by having interest and participation from the society and uplift parental contribution in children's learning through older options (spread of information verbally and written) and latest alternatives when people watch programmes on television, informations from conversations through phones and entry of electronic messages through mails. In cases of individuals who deem non-traditional strategies, older options don't seem to fit in. When Kwatubana and Makhalemele (2015:317) did a study, it is found that some education institutions avoided strategies of sound-based which could drive parental performance in their children' class activities. The Free State within the same study was determined to sweepstake parents who are in the food industry. This plan of action will be a hit when the school ought to put an end to prejudice among parents.

The application of a positive impact alternative in order for parents to get involve can change the way they look at situation as they gradually are on the look in knowing the benefits of getting engaged with their children's growth in learning and later on to see the good outcomes. This can further be enhanced by aiding families of non-English speakers by helping them with particulars of translations in order to help them in their native language. (Lemmer.2007:221) 


\section{Conclusion}

When parents step into their children's education, the outcomes will turn out to be positive ones be it primary or higher education and this takes into account of skills in tutorial, good attitude and high social interactability (Lau, Li \& Rao, 2011:97). Speaking of parental involvement, the uttermost thing is that it moulds a learning platform for kids to strive further and explore all the good things as well as driving them to expand their wings and horizon in creating those proud moments of achievements for their closed one.

\section{References}

[1] Alexander, P. A., Schallert, D. L. \& Reynolds, R. E. 2009. What Is Learning Anyway? A Topographical Perspective Considered. Educational Psychologist 44(3):176-192.

[2] Baker, A. (1997). Parents as School Partners. National Council of Jewish Women from http://ericweb.tc.columbia.edu/npinpdfs/parents_as_partn ers.pdf. $2^{\text {nd }}$ December 2002

[3] Baker, D.P., \& Stevenson, D.L. (1986). Mothers' Strategies for Children's School Achievement: Managing the Transition to High School. Sociology of Education, 59, 156-166. Becher, R. (1986). Parents and Schools. (ERIC Document Reproduction Service No. ED269137).

[4] Bloom, B.S. (1980). The New Direction for Educational Research: Alterable Variables. Phi Delta Kappan :61, 382-385.

[5] Brown, P. (1989). Involving Parents in the Education of Their Children. (ER(C Document Reproduction Service No. ED308988).

[6] Christenson, S.L., Rounds, T., \& Gorney, D. (1992). Family Factors and Student Achievement: An Avenue to Increase Students' Success. School Psychology Quarterly: 7, 178-206.

[7] Clinton, J. \& Hattie, J. 2013. New Zealand Students' Perceptions of Parental Involvement in Learning and Schooling. Asia Pacific Journal of Education 33(3): 324337.

[8] De Carvalho, M. (2001). Rethinking family-school relations. Mahwah, NJ: Lawrence Erlbaum. DelgadoGaitan, C. (1991). Involving Parents In The Schools: A Process of Empowerment. American Journal of Education: 100, 20-46.

[9] Deslandes, R., Royer, E., \& Turcotte, D. (1997). School Achievement at The Secondary Level: Influence of Parenting Style and Parent Involvement in Schooling. McGill Journal of Education 32, 191-207. Retrieved December 1, 2002 .WilsonSelectPlus database.

[10] Dornbush, S.M., Ritter, P.L., Leiderman, P.H., Roberts, F.D., \& Fraleigh, M.J. (1987). The Relation of
Parenting Style to Adolescent Performance. Child Development 58: 1244-1257.

[11] Epstein, in Jones, Rebecca. (2001). Involving parents is a whole new game: Be sure you win! The Education Digest, 67 (3), 36-43. Jones, Rebecca. (2001). Involving Parents is a Whole New Game: Be Sure You Win! The Education Digest 67 (3): 36-43.

[12] Epstein, J.L. (1987). Parent involvement: What Research Says to Administrators; Education and Urban Society 19(2): 119-136.

[13] Epstein, J.L. (1995). School/family/community partnerships. Caring for The Children We Share. Phi Delta Kappan, 76(9): 701-712.

[14] Epstein, J.L. (1996). Family-school links: How Do They Affect Educational Outcomes? In A. Booth \& J. Dunn (Eds.), Family-school links: How Do They Affect Educational Outcomes? Hillsdale, NJ: Lawrence Erlbaum. Interview with Joyce

[15] Garcia, L.E. \& Thornton, O. 2014. The Enduring Importance of Parental Involvement. http://Neatoday.org/2014/11/18/the- enduring-importance of parentalinvolvement-2/. 13th March 2018.

[16] Hornby, G. \& Lafaele, R. 2011. Barriers to Parental Involvement in Education: An Explanatory Model. Educational Review 63(1):37-52

[17] Keith, T.Z., Reimers, T.M., Fehrmann, P.G., Pottebaum, S.M., \& Aubrey, L.W. (1986). Parental involvement, homework, and TV times: Direct and Indirect Effects on High School Achievement. Journal of Educational Psychology 78: 373-380. 67

[18] Khajehpour, M. \& Ghazvini, S. D. 2011. The Role of Parental Involvement Affect in Children's Academic Performance. Procedia Social and Behavioural Sciences 15(2011):1204-1208.

[19] Kwatubana, S. \& Makhalemele, T. 2015. Parental Involvement in the Process of Implementation of the National School Nutrition Programme in Public Schools. International Journal of Educational Sciences 9(3):315323

[20] Lau, E. Y.H., Li, H. \& Rao, H. 2011. Parental Involvement and Children's Readiness for School in China. Educational Research 53(1): 95-113.

[21] Lemmer, E. M. 2007. Parent Involvement in Teacher Education in South Africa: International Journal about parents in Education 1(0): 218-229.

[22] Llamas, A.V. \& Tuazon, A. P. 2016. School Practices in Parental Involvement, Its Expected Results and Barriers in Public Secondary Schools: International Journal of Educational Science and Research 6(1):69-78.

[23] Sapungan, G.M. \& Sapungan, R. M. 2014. Parental Involvement in Child's Education: Importance, Barriers and Benefits. Asian Journal of Management Sciences and Education 3(2): 42-48. 
[24] Scribner, J. D. \& Mahitivanichcha, K. 2001. Redefining Parental Involvement: Lessons from High Performing Migrant-Impacted Schools. American Education Research Journal 38(2): 253-288

[25] Sigh, P., Mbokodi, S. M. \& Msila, V. T. 2004. Black Parental Involvement in Education: South African Journal of Education 24(4):301-307. 